\title{
"The Other Side of the Coin": What Do Business Schools Teach the Typical Business Undergraduate Student About the Nonprofit Sector? A Case Study From the Netherlands
}

\author{
Lucas C. P. M. Meijs \\ Esther M. Ten Hoorn \\ Erasmus University \\ Jeffrey L. Brudney \\ Cleveland State University
}

\begin{abstract}
This article focuses on the exposure of the typical undergraduate business student to the nonprofit sector and management, as opposed to focusing on learning opportunities available to interested students in particular, as is typically reviewed in research on nonprofit management education. To address this novel question, the authors employed a multimethod research strategy to investigate the coverage of the nonprofit sector in the undergraduate business degree program of a leading international business school: the Rotterdam School of Management, Erasmus University in the Netherlands. Based on an exhaustive review of course syllabi, interviews with faculty members, systematic analysis of course lecture notes, and a student discussion group, the results show rather tepid attention to the nonprofit sector and management in the undergraduate curriculum. The article concludes with a discussion of the implications of these findings for instruction of business administration undergraduate students to prepare them for interaction with the nonprofit sector.
\end{abstract}

Keywords: business school; curriculum; nonprofit; education

Although there is growing interest in collaboration and partnerships between for-profit organizations and nonprofit organizations (NPOs), there seems to be limited interest at business schools in teaching about nonprofits. Of course, business schools are offering electives and, in a few cases, even degree programs on nonprofit management, as documented by the Seton Hall University Project to "examine the impact of nonprofit management education programs on the nonprofit community" (Mirabella, n.d.). The Seton

Nonprofit and Voluntary Sector Quarterly, Supplement vol. 36, no. 4, December 200780 S-97S

DOI: $10.1177 / 0899764007305050$

(C) 2007 Association for Research on Nonprofit Organizations and Voluntary Action

$80 S$ 
Hall University Project encompasses universities in the United States (and around the world) and looks at what nonprofit management courses and concentrations are offered. The researchers found more than 250 colleges and universities with courses in nonprofit management. Some (American) business schools have also incorporated community service or service learning into their programs (see, for example, the Service Learning special issue of Academy of Management Learning \& Education, Baily, 2005), although "European business schools have not yet discovered the added value of service learning" (van der Voort, Meijs, \& Whiteman, 2005, p. 150).

Research on nonprofit education in schools of business and other disciplines focuses primarily, if not exclusively, on the learning opportunities open to business (and other) students who wish to take advantage of the knowledge and instruction available in this domain (see, for example, Mirabella \& Renz, 2001; Mirabella and Wish, 1999, 2000, 2001; Nonprofit Management Education, n.d.). Although the Seton Hall University Project and the research and commentary it has generated have been useful in documenting the existence of nonprofit educational offerings for students who may want them, the literature has not dealt with "the other side of the coin": In the Bachelor of Arts curriculum, what will the average undergraduate business student, who typically does not have an abiding interest in nonprofits and who most likely will not seek out the relevant elective courses, learn about the nonprofit sector?

This research examines how much attention is given to the nonprofit sector and nonprofit management in a regular business bachelor's degree program in which students generally do not enroll in the nonprofit management electives. Given the breadth and novelty of our research question, our study is exploratory: Using a multimethod research strategy, we present an in-depth case study of the coverage of the nonprofit sector in the undergraduate business degree of a single university: the Rotterdam School of Management (RSM), Erasmus University, the Netherlands. Our study is based on an exhaustive review of course syllabi, interviews with faculty members, a systematic analysis of course lecture notes, and discussion and commentary from business students. A case study has limitations, but it is appropriate and useful for an exploratory inquiry such as this one (O'Sullivan, Rassel, \& Berner, 2003).

We selected the RSM Erasmus University for our study because it is the leading business school in the Netherlands and, indeed, ranked second in 2006 only to the University of London-London Business School among international business schools according to ratings compiled by the Social Science Research Network (2006). ${ }^{1}$ The selection of this institution as the focus of our inquiry offers the advantage of illustrating the upper limit of knowledge of the

Note: This is a revised version of a paper presented at the BenchMark 3 Conference on Nonprofit and Philanthropic Studies, March 16-19, 2006, Tempe, Arizona. The authors thank Nadia Dajani, junior researcher at the Rotterdam School of Management, Erasmus University, for her assistance and the Stichting Intermediair Rotterdam, Erasmus University, for providing all business administration bachelor's lecture notes summaries. 
nonprofit sector and management to which the average undergraduate business student would be exposed in the course of their degree program. We would expect to find the greatest curricular coverage of the nonprofit sector in the more cosmopolitan, renowned, and progressive business schools with a strong student body, such as RSM Erasmus University. Thus, the results of our study should yield the most optimistic assessment concerning the other side of the coin, that is, the curricular exposure of the typical undergraduate business student to the nonprofit sector or management. In our opinion, most business schools are likely to fall short of this high water mark.

\section{THE CASE FOR NONPROFIT COVERAGE IN THE UNDERGRADUATE BUSINESS CURRICULUM}

Before presenting our case study, it is worth briefly considering why schools of business administration should devote attention to the nonprofit sector or management in the undergraduate curriculum. At eminent business schools such as RSM Erasmus University especially, faculties educate the future business leaders of society. Their graduates will be called upon to make many important decisions concerning public issues and NPOs for which basic knowledge about the sector is useful, if not essential.

NPO chief executive officers often turn to for-profit organizations to garner corporate assistance with funding, in-kind contributions, and expertise. They seek partnerships, alliances, and collaborations of innumerable scope and variety with private businesses. They target and ask business people to head their fund raising, capital, and other campaigns. They endeavor to persuade business leaders to help them make their case for increased funding, favorable legislation, greater support, and so forth before government, the media, and the public. For their part, many businesses want to demonstrate their commitment to corporate social responsibility, which often prompts interaction with the nonprofit sector (see, e.g., Austin, 2000; van Tulder, 2006; Wartick \& Wood, 1999).

Another reason to educate future business leaders on the nonprofit sector and management is so "business leaders serving as nonprofit board members will better understand their nonprofit roles" (Taliento \& Silverman, 2005). Herman (2005, pp. 80-81) estimated that the number of NPOs in the United States needing board members is $1,228,000$. The Dutch official Chamber of Commerce (http://www.kvk.nl/handelsregister/zoekenframeset.asp?url= https://server.db.kvk.nl/wwwsrvu/html/zoek.htm searched for stichtingen [foundations] and vereniging [association]) put the number of NPOs in the Netherlands with a need for board members at about 250,000. Of course, not all board member seats go to business people, and overlapping memberships across boards do occur. Yet the demand on the business community is evident.

Business people are likely to interact with NPOs as a result of several other factors. These include job opportunities in the nonprofit sector (an 
analysis of the RSM Alumni Association database suggests that an estimated $5 \%$ of business administration alumni are employed in the nonprofit sector) and high rates of volunteering, philanthropy, and association membership (Weitzman, Jalandoni, Lampkin, \& Pollak, 2002). In fact, the Netherlands scores highest of any nation on the Civil Society Index constructed by Salamon, Sokolowski, and Associates (2004, p. 78). Given the decisions they will be called upon to make and the interpenetration of the sectors, it seems advisable for business schools to offer their graduates a basic background in nonprofits.

\section{RESEARCH QUESTION}

In this research, our goal is to learn what ordinary business studentsthose who do not elect nonprofit management courses-are taught about the nonprofit sector through the standard curriculum. With what basic knowledge does their business degree provide them to participate in the nonprofit sector and to render important decisions concerning NPOs? The background these students receive will affect not only how future business leaders interact with the nonprofit sector but also the prospects of the NPOs they encounter.

To address our research question, we sought to determine how much coverage the undergraduate curriculum and instruction in business administration at RSM Erasmus University gives to three broad aspects of nonprofit knowledge:

1. general information about the nonprofit sector, such as size, scope, services, purpose, role in the economy and larger society, funding, importance, and so forth;

2. nonprofit management in comparison to for-profit management, such as similarities and differences, relative strengths and limitations, transferability of knowledge across sectors, and so forth; and

3. for-profit-nonprofit relations, such as joint projects, partnerships, stakeholder dialogue, grants, contracts, job opportunities, service on boards of directors, and so forth, which bring the sectors into closer proximity and alliance.

Educational coverage of the first of these areas pertains to the most fundamental aspects of the nonprofit world. It provides a necessary part of the context for students to understand how societies go about meeting the essential needs of their citizens through division of activity among the nonprofit, for-profit, and public sectors. Our experience in schools of business administration leads us to speculate that although a great deal has been written about the nonprofit sector in general, most of the publications are only available to and used by special audiences (e.g., nonprofit management 
students, nonprofit managers) and in dedicated courses (e.g., in nonprofit management). To our knowledge, little if any attention is devoted to nonprofits by general business majors or by practicing business managers.

Similarly, we find it remarkable how little attention is given to the last two of these topics in the general management education literature. For instance, the Rethinking Management Education and Development Series (Wankel \& DeFillippi, 2002-2006) focuses almost completely on general business management and the private sector. Not even a single chapter in this five-volume series covers nonprofit management in comparison to for-profit management, and the topic of for-profit-nonprofit relations is dealt with only once in "Using a Non-Profit Business Partner to Develop Business Management Skills for MBA Education" (Sherman and Coombs, in press). In the same series, service learning receives greater attention (three chapters). In addition, our search revealed virtually no attention given to nonprofits in one of the leading journals on management education, Academy of Management Learning $\mathcal{E}$ Education. Only its special edition on service learning shows attention (just once) to building business partnerships with NPOs to enable service learning.

In our judgment, there is much more literature on teaching management to nonprofit people than there is on teaching nonprofits to business people. This imbalance is surprising given Drucker's (1989) call to the business community in the Harvard Business Review to integrate "What Business Can Learn From Nonprofits." We are not the only ones who struggle with this issue, as our search of the literature revealed. Stead and Miller (1988) wondered how social awareness can be increased through the business school curriculum. Hess (n.d.) observed that "although nonprofit organizations are a major sector of economic activity and many students will eventually find employment in this area, it tends to be neglected in the finance curriculum" (p. 1). Hess proposed to enrich the finance curriculum by applying key financial concepts to nonprofits (e.g., goal of the firm, financial markets, valuation, financial analysis, financial forecasting, risk and return, financing options, etc.). We also found that human resource management could benefit from nonprofit management: Managing employees as if they were volunteers (Smith \& Green, 1993) and helping employees to volunteer could contribute to better human resource management (Ulrich, 1997).

The second topic, comparing nonprofit to for-profit management, can be seen in the perspective of Eliassen and Kooiman (1993). Their study on new public management includes a simple matrix that can be adapted to this discussion. They presented four possible positions concerning the comparability between public- and private-sector management (p. 5). Table 1 summarizes their perspective. We can say normatively that nonprofits should (similarity) or should not (dissimilarity) be managed like businesses, and that in reality they are (similar) or are not (different) managed in these ways. Researchers and practitioners who see many similarities between public and private 
Table 1. Public and Private Management Differences

\begin{tabular}{lcc}
\hline & \multicolumn{3}{c}{ Normatively } \\
\cline { 2 - 3 } In Reality & Similarity & Dissimilarity \\
\hline Similar & I & II \\
Different & III & IV \\
\hline
\end{tabular}

Source: Eliassen \& Kooiman (1993, p. 6).

management can be classified as Type I. The opposite is Type IV, those who believe that public management is different from private management not only in practice but also in basic principles. Researchers and practitioners who see both similarities and differences between the sectors fall between these two endpoints (Type II and Type III). For example, those who feel that management across the sectors should be more similar than is often exhibited in practice are Type III. Conversely, researchers and practitioners falling into Type II find more similarity in management practice across sectors than they believe is warranted in theory. The matrix shown in Table 1 is consistent with Fottler (1981), who claimed that private for-profit, private nonprofit, private quasi-public, and public organizations have different management functions because they gain support from different stakeholders. Adapting the Eliassen and Kooiman matrix to nonprofit versus for-profit management, we see that there is no one correct choice for business faculty to adopt in their teaching (or avoidance) of the nonprofit sector or management. The mix of normative and empirical perspectives on the comparability of the forprofit and the nonprofit sectors illustrated by the matrix will affect how faculty approach teaching in this area.

The third issue we address in the business school curriculum, businessnonprofit relations, can be placed in the debate on corporate social responsibility and corporate community involvement. Within the stakeholder dialogue literature (for example, van Tulder, 2006) the relationship concentrates mainly on advocacy or campaigning nongovernmental organizations (NGOs) such as Greenpeace and Amnesty International. Business partnerships with NGOs are used to influence the opinion of these and other stakeholders, such as investors. For the NGO, the partnership offers possibilities to influence the behavior of key business players and consumers. Within the nonprofit partnership literature (e.g., Austin, 2000) the partnerships between service-delivery NPOs and businesses are seen as a way to achieve public relations or human resource management goals of the for-profit company. For the NPO, the partnership generates additional resources. ${ }^{2}$

Based on our review of the scant literature available, we conclude that little attention has been devoted to the other side of the coin: the coverage of the nonprofit sector and management in the undergraduate business curriculum. We investigate curricular coverage in the analysis below. 


\section{RESEARCH METHODS}

Educating future business leaders and advancing business knowledge are the two main goals of the RSM Erasmus University. We conducted our research in this leading business school (see above) with the idea that it would have the most progressive policies concerning education in nonprofit organization, leadership, and management. One indication is that the RSM has a department of Business-Society Management concerned with these larger issues. Our analysis should thus reveal the maximum exposure that a typical business undergraduate student is likely to receive to the nonprofit sector and management. With more than 188 faculty in 2006, the RSM has the largest faculty at Erasmus University; more than 500 students enter the RSM bachelor's program annually. ${ }^{3}$

To investigate coverage of the nonprofit sector and management in the bachelor's degree business curriculum at RSM Erasmus University, we employed a multimethod research strategy. We began by reviewing the entire curriculum description, standards, course manuals, and associated materials for all bachelor's degree courses in business administration. We supplemented this foundation with information gained from three other research methods:

- a survey of primary faculty members who teach in the business administration curriculum,

- a systematic analysis of the lecture notes from these courses prepared for sale to business students; and

- a group discussion with graduate students in the master's degree elective program in nonprofit management who had earned the business administration degree at RSM Erasmus University.

\section{FACULTY SURVEY}

We prepared and sent a short survey by e-mail to the primary faculty teachers of the 32 core bachelor's degree courses in the RSM Erasmus business administration program. We followed up with telephone calls to the nonresponding teachers. In all, teachers from 25 courses responded, representing $78.1 \%$ of the total number of business administration bachelor's degree courses offered at RSM (32). ${ }^{4}$

Consistent with the topics elaborated above, we asked the faculty members to comment and elaborate on three questions:

In your lectures or assignments,

- do you give attention to the nonprofit sector in general?

- do you give attention to nonprofit versus for-profit management?

- do you give attention to for-profit-nonprofit relationships? 


\section{ANALYSIS OF COURSE LECTURE NOTES}

To validate the claims from faculty members regarding nonprofit coverage in their classes, we obtained and scanned by computer the electronic version of the student lecture notes of all lectures in the three bachelor's years, which are produced by a student (nonprofit) organization (Stichting Intermediair Rotterdam [SIR]). Students consider the SIR lecture notes of reasonable quality; in some cases they are checked by the lecturers. The student note-takers are paid, and many students purchase the notes. From our sample of 25 courses in the RMS bachelor's degree program, the SIR lecture notes cover 22 courses for the 2004-2005 academic year. ${ }^{5}$ In total we checked (scanned) electronically 2,842 pages (about 220 lectures, excluding tutoring classes from 22 courses) for the following search terms: nonprofit, non-profit, non profit, NPO, vrijwillig (voluntary/volunteer), NGO, non-governmental, non governmental, not-for-profit, not for profit, NFP, vereniging (association), stichting (foundation). We also checked gezondheidszorg (health care), sport, and musea (museums) because these sectors are dominated by nonprofits in the Netherlands. ${ }^{6}$

\section{GROUP DISCUSSION WITH GRADUATE STUDENTS IN THE ELECTIVE PROGRAM IN NONPROFIT MANAGEMENT}

Finally, we conducted a group discussion with 12 students enrolled in the master's elective in nonprofit management who had earlier obtained the bachelor's degree in business from RSM Erasmus University. This group of nonprofit management elective students was expected to have a more accurate memory of attention to nonprofits in their bachelor's courses than other students would because they have shown an interest in nonprofits by choosing this elective. As a result, we anticipated that they would remember more accurately what they had learned about nonprofits in their bachelor's degree courses at RSM. We asked these students about attention in their bachelor's courses to (a) the nonprofit sector in general, (b) nonprofit management versus for-profit management, and (c) profit-nonprofit relations-the same general questions or topics that we had posed to faculty members. We asked the graduate students to mention examples, names of courses, names of organizations, and so forth relating to nonprofits that they could recall from lectures, tutorials, exercises, examinations, and the like. In addition to the students who participated in the group discussion, 6 students sent e-mail responses recounting their remembrances of attention to the nonprofit sector and management in their bachelor's degree program.

The three data sources are quite different, and each has its particular advantages and limitations. Together, they bring significant breath and depth to our study. We turn now to the findings yielded by these different research methodologies. Table 2 summarizes the results of our inquiry concerning coverage of the nonprofit sector and management in the undergraduate business curriculum at RSM Erasmus University. ${ }^{7}$ 
Table 2. Coverage of Nonprofit Themes in the Undergraduate Business Curriculum

\begin{tabular}{|c|c|c|c|}
\hline $\begin{array}{l}\text { Number } \\
\text { of } \\
\text { Courses }\end{array}$ & Course Titles & $\begin{array}{c}\text { Attention to } \\
\text { Nonprofit } \\
\text { Themes } \\
\text { According } \\
\text { to Teachers }\end{array}$ & $\begin{array}{l}\text { SIR Summaries } \\
\text { Confirmation }\end{array}$ \\
\hline \multirow[t]{3}{*}{3} & Information Management & All 3 & 1 of 3 \\
\hline & Management Skills & All 3 & 2 of 3 \\
\hline & Business-Society Management & All 3 & Confirmed teachers \\
\hline \multirow[t]{2}{*}{2} & Business Skills & 2 of 3 & Unavailable \\
\hline & Market Research & 2 of 3 & 1 of 3 \\
\hline \multirow[t]{9}{*}{9} & Management Accounting & 1 of 3 & Confirmed teachers \\
\hline & Marketing Management & 0 of 3 & 1 of 3 \\
\hline & Market Context & 1 of 3 & 0 of 3 \\
\hline & Operations and Logistics Management & 1 of 3 & 0 of 3 \\
\hline & Financial Processes & 1 of 3 & Confirmed teachers \\
\hline & Methodology & 1 of 3 & 0 of 3 \\
\hline & Introduction to Business Administration & 1 of 3 & Confirmed teachers \\
\hline & Organizational Dynamics & 1 of 3 & 0 of 3 \\
\hline & Science Doctrine & 1 of 3 & 0 of 3 \\
\hline \multirow[t]{11}{*}{11} & Statistics & 0 of 3 & Unavailable \\
\hline & Financial Accounting & 0 of 3 & Confirmed teachers \\
\hline & Primary Processes & 0 of 3 & Confirmed teachers \\
\hline & Decision Processes & 0 of 3 & Confirmed teachers \\
\hline & Statistics (Bachelor 2) & 0 of 3 & 1 of 3 \\
\hline & $\begin{array}{l}\text { Strategic Environment Management and } \\
\text { International Business }\end{array}$ & 0 of 3 & Confirmed teachers \\
\hline & Human Resource Management & 0 of 3 & 1 of 3 \\
\hline & Operations Research and Modeling & 0 of 3 & Confirmed teachers \\
\hline & Company Law & 0 of 3 & 1 of 3 \\
\hline & Mathematics & 0 of 3 & Unavailable \\
\hline & Corporate Finance & 0 of 3 & 1 of 3 \\
\hline
\end{tabular}

Note: Stichting Intermediair Rotterdam $=$ SIR.

\section{RESULTS}

\section{FINDINGS BASED ON THE SURVEY OF RSM FACULTY MEMBERS}

Three courses give attention to all three nonprofit themes investigated. The findings presented below are based on an in-depth review of the curriculum and course materials in the bachelor's degree program in business administration at RSM Erasmus University and our survey and interviews with business faculty. We found that through lectures, tutorials, and assignments for students, a total of three courses give explicit attention to all three of the areas under investigation: the nonprofit sector in general, nonprofit management in comparison to for-profit management, and the relation between for-profits and nonprofits. 
The core course Business-Society Management, normally taken in the third year by business students, presents information on the relationships among the market, state, and nonprofit sector, with an emphasis on ethics. Although this course does not devote specific attention to nonprofit management, one lecture does deal with business-nonprofit relations, including a small segment on nonprofit management.

A second course, Management Skills, pays considerable attention to nonprofits. It gives students the opportunity to spend the day with a manager of a for-profit or a nonprofit organization. The required reading for the course includes articles on nonprofits and partnerships between NPOs and businesses, a course assignment pertains to NPOs, and the final examination probes this knowledge. Finally, a guest speaker from the Dutch Red Cross presents a lecture and discussion on management skills from a nonprofit point of view.

It is surprising that the lecturer in the course Information Management regularly gives attention to all three areas of nonprofits encompassed by our research. Regarding the nonprofit sector in general, the course sometimes gives attention to new techniques from the nonprofit sector, such as electronic health and e-government. Students are free to choose an NPO as the subject for their assignments, and an estimated 15 to $20 \%$ do so. When technological innovations from the nonprofit sector are discussed in class, attention is devoted to the implications for management. However, the primary focus of this discussion is meant to benefit for-profit organizations rather than to enhance management of this innovation in NPOs. Innovations from nonprofits that are interesting to for-profits are discussed in class but only from the point of view of "What can for-profits learn from nonprofits?"

Two courses give attention to two of the three nonprofit themes investigated. We found that two courses, Business Skills and Market Research, give attention to two of the themes regarding NPOs investigated in this study. In Business Skills the instructor organizes a debate at which representatives of the nonprofit sector are invited to discuss societal and management issues.

From time to time, the course Market Research draws on examples from the nonprofit sector-but without mentioning to the business students that the cases are NPOs. The course also gives some attention to the relation between for-profits and nonprofits. Occasionally an illustration is presented with reference to the nonprofit sector, for example, that nonprofits typically have smaller budgets than businesses do. Yet the relationship between the sectors is not discussed directly.

Nine courses give attention to one of the three nonprofit themes investigated. Our survey shows that in the Management Accounting lectures and workshops, attention is rarely given to the nonprofit sector in general. The instructor told us: 
I now and then mention that the management accounting tools can be used in the nonprofit sector as well. Also, the textbook mentions this, but no more than that. My personal opinion is that I think that we should focus more often on the nonprofit sector, in our teaching as well as in my research field [accounting and control]. Especially in management accounting and control we hardly focus on the nonprofit sector or on controlling aspects of for-profit-nonprofit relationships.

In the course Marketing Management, a question on one of the assignments sometimes asks students to apply marketing concepts to NPOs. No further attention is given to nonprofits during the lectures, however.

The course Market Context devotes slight attention to the relationship between nonprofits and for-profits. It presents some coverage of the organizational structure of governmental and nonprofit organizations and what businesses can learn from these organizations, but the treatment is rather cursory. The course pays some attention to societal issues, such as the Microsoft antitrust trial.

Another course that gives slight attention to the relationship between the for-profit and nonprofit sectors is Introduction to Business Administration. Once during the course the instructor noted that businesses can market a $\mathrm{NPO}$ as part of their marketing strategy. The required literature for the course also makes this point.

One course that gives attention to nonprofit management is Operations and Logistics Management. In the classes and the assignments, the course concentrates on the social sectors of health care and criminal justice. The course checks whether nonprofit management practices are relevant and useful to business.

Among these nine courses, most attention is given to the nonprofit sector in general. For example, the course Financial Processes only mentions the concept in the first, introductory class. In the course Science Doctrine, when explaining assumptions of economic theories, the lecturer merely mentions that not-for-profit organizations also exist.

In the lectures for the Methodology course, about $15 \%$ of the example cases mention nonprofits. Given the focus of the course, the context is mainly to illustrate methodological concepts: For instance, when using a qualitative research method such as interviewing, nonprofits should be included as one of the stakeholders.

Finally, in the course Organizational Dynamics, some of the examples and cases presented in the lectures are nonprofits, for example, universities and municipalities (which are, of course, governments but are presented by the instructor as nonprofits). In this class the teacher draws from her own experiences to give examples of NPOs.

Eleven courses do not give attention to any of the nonprofit themes investigated. The remaining courses give no attention to the three areas that we inquired 
about: Statistics, Financial Accounting, Primary Processes, Decision Processes, Statistics (Bachelor 2), Strategic Environment Management and International Business, Human Resource Management, Operations Research and Modeling, Company Law, Mathematics, and Corporate Finance.

\section{FINDINGS BASED ON THE SIR LECTURE NOTES}

To crosscheck the information provided by the faculty members summarized in Table 2, we electronically searched all lecture notes from the available 22 business administration bachelor's courses for 2004-2005 prepared by SIR. On average there were about 10 lectures per course in the lecture notes, summarized in 2,842 pages. The nonprofit search terms that we used (and how many times they were encountered in the lecture notes) in order of frequency are as follows: NGO (28), nonprofit or non-profit (21), volunteer or voluntary (21), association (25), foundation (13), sport (10), museum (7), health care (5), not for profit or not-for-profit (0), and NPO (0), for a total of 130 references.

These 130 references appear in the notes of 28 lectures from 14 courses (out of about 220 lectures from 22 courses, excluding tutoring classes), mainly Macro-Economic and Institutional Context, Business-Society Management, Management Skills, Human Resource Management, Market Research, and Company Law (minimum of 5 hits). The attention is often concentrated in one single example or paragraph in which the search term appears several times. The attention is limited to the nonprofit sector in general or a NPO as an example of a business concept, except for lectures from Macro-Economic and Institutional Context and Business-Society Management that dealt with partnerships, and lectures on Management Skills that briefly touched on nonprofit management. Eight lectures from a single course, Business Society Management, account for 37 of the 70 times the terms nonprofit or non-profit, volunteer, voluntary, and NGO appear, thus suggesting that the curriculum devotes very little attention to nonprofits beyond this one course.

The last column of Table 2 summarizes our analysis of the SIR course lecture notes. This analysis tends to confirm the claims of the faculty member interviews regarding coverage of the nonprofit sector and management in nine courses: Business-Society Management, Management Accounting, Financial Processes, Introduction to Business Administration, Financial Accounting, Primary Processes, Decision Processes, Strategic Environment Management and International Business, and Operations Research and Modeling. The claims of the faculty members were not directly confirmed for 10 courses. The teachers of Information Management claimed to address all three areas, but in the lecture notes we found coverage of just one area, and in Management Skills we found attention to only two areas instead of all three. The teacher of Market Research claimed to pay attention to two of three areas, but the SIR lecture notes showed attention to only one area. 
As Table 2 shows, many faculty members claimed to pay attention to one of the three nonprofit areas in their lectures. The SIR lecture notes did not confirm this conclusion for several courses: Marketing Management, Market Context, Operations and Logistics Management, Methodology, Organizational Dynamics, and Science Doctrine. It is surprising that we did find some attention to the nonprofit sector in general in the notes for four courses that, according to the teachers, did not deal with nonprofits at all: Statistics (Bachelor 2), Human Resource Management, Company Law, and Corporate Finance.

In two courses for which the teachers did not reply to our survey, the SIR lecture notes show some attention given to nonprofits (Organizational Behaviour and Theory, Strategy Development and Implementation). The teachers of Psychological and Social Processes and Innovation Management also did not respond to our survey, and here the lecture notes reveal no attention to nonprofits.

\section{FINDINGS BASED ON THE DISCUSSION GROUP OF STUDENTS IN THE NONPROFIT MASTER'S ELECTIVE}

In the group discussion with 12 students from the master's elective in Nonprofit Management, the students at first remembered very little about nonprofits from their undergraduate business education at RSM. After some prompting by the researchers, the students gradually remembered partnerships and general nonprofit information presented in such courses as Macro-Economic and Institutional Context, Management Skills, and Business-Society Management. In their recollection, the courses had not mentioned the nonprofit sector or nonprofit management specifically. Although the students could remember references to sport and other associations as examples of business practices, the teachers had not explicitly identified the organizations as nonprofit. The students felt that the instructors had made these references because they were familiar to the students and, thus, readily comprehended-not because their nonprofit status mattered or was important in the context of their management education. In fact, some students explained that only now after having followed the elective nonprofit management courses had they come to understand that these example organizations were nonprofit. The six e-mail responses received from other students reinforce these findings.

\section{DISCUSSION}

Table 2 summarizes coverage of the nonprofit sector in general, nonprofit management in comparison to for-profit management, and the relationship between for-profits and nonprofits in the bachelor's degree program in business administration at RSM Erasmus University. Based on our review and 
analysis of 25 core business courses with the principal teachers, only 3 courses give attention to all three themes. Two courses give attention to two of three themes, and 9 courses give attention to one of the three themes. Finally, 11 courses do not devote attention to the nonprofit sector or management.

Examining the responses from the business faculty to the three questions we posed to them regarding the nonprofit sector, we find that 11 courses give attention to the nonprofit sector in general. The attention varies from inviting guest speakers from the nonprofit sector to nonprofits being included as part of an assignment. We should note that these courses present NPOs almost exclusively as illustrative examples or cases for business management, rather than as topics worthy of study or practice in their own right.

Only three courses give attention to nonprofit management. The attention is intended in a positive way, mainly to see if there are interesting things businesses can learn from nonprofits. Six courses give attention to for-profit-nonprofit relations, again to determine if NPOs have useful applications to business. Referring to the Eliassen and Kooiman (1993) matrix, we found that most faculty members appear to fall into Type I and sometimes the Type III or Type IV categories (see Table 1). Type I teachers see nonprofits and businesses generically as organizations and use examples of both kinds without distinguishing nonprofits. Type III teachers see nonprofits as different but potentially interesting to business managers (and students). Type IV teachers think that nonprofits are too different from businesses to be relevant to business students: This perspective may help to explain why there is not greater coverage of nonprofits in the RSM business administration undergraduate curriculum.

In sum, based on our extensive examination of the formal curriculum and survey of faculty members in the undergraduate business degree program at RSM Erasmus University, our overall impression is that few courses give substantial attention to nonprofits. Most courses present no coverage or only very little attention to the nonprofit field. The analysis of the SIR lecture notes as well as the results of the group discussion of graduate students enrolled in the RSM elective nonprofit program confirm this conclusion.

We hasten to add-as we pointed out at the outset of this article- that if students in business administration are interested in knowledge and education about the nonprofit sector, they can find appropriate courses or concentrations, especially at the graduate level. The Seton Hall University project documents the availability of courses, concentrations, and degree programs in nonprofit organization and management (Mirabella, n.d.). This conclusion certainly applies to RSM. Graduate students who seek formal education or management in the nonprofit sector can enroll in the RSM Master's of Global Business and Stakeholder Management program, elective courses in nonprofit management, and supervised research and projects for academic credit on NPOs. In addition, a service learning program, experimental in the Dutch setting and aimed at building consulting skills, learning about the nonprofit sector, or concentrating on a particular topic (such as business 
community involvement), began at RSM Erasmus University in 2004 (see van der Voort, Meijs, \& Whiteman, 2005).

The availability of educational opportunities in nonprofit sector management to a self-selected group of graduate students interested in them is not our focus here, however. Instead, the focus of our research is on the other side of the coin-that much larger segment of undergraduate students in business administration who have no particular interest in or attraction to the nonprofit sector or management. In the bachelor's degree program in business administration, what will the average undergraduate student who typically does not have an abiding interest in the nonprofit sector-and who most likely will not seek out courses in this area-learn about the nonprofit sector?

If the results of this intensive, multimethod study of a leading international business school offer any guide, we might have expected-or hoped for-greater coverage in the undergraduate business curriculum. In our opinion, moreover, given the size and distinction of RSM Erasmus University, our findings represent the high water mark of what the typical business administration undergraduate student might be exposed to in this domain: Other smaller, less renowned universities are likely to have fewer faculty, resources, and courses to devote to undergraduate education in the nonprofit sector and management.

\section{CONCLUSION}

Schools of business administration are responsible for preparing students for careers in the private sector. Most of their baccalaureate graduates will work in business-but they will also encounter the nonprofit sector. NPOs solicit help and support from for-profit organizations for funding, expertise, and volunteers. They are interested in partnerships, alliances, and collaborations with private businesses. They target business executives for service on boards of directors and in fund raising and other campaigns. They entreat business leaders to assist them in making a case for funding, legislation, and support that will help persuade government, the media, and the public. How will business people respond to these requests?

Part of the answer lies in what ordinary business students enrolled in the standard undergraduate curriculum are taught about the nonprofit sector. This research has investigated the basic knowledge that the bachelor's degree in business administration provides them to render important decisions concerning the nonprofit sector. Our research has limitations, of course: It is a case study, albeit one strengthened significantly by the use of a multimethod research strategy. Although the focus is on a single entity, we selected the RSM Erasmus University purposely as a recognized international leader in business administration to illustrate the upper limit of coverage that a typical undergraduate business student is likely receive in the nonprofit sector and management. We were not able to observe the actual presentation of 
nonprofit material in classes or assignments at the RSM; however, to make our judgments we carefully collected information from course syllabi and the instructors as well as from students with an interest in this area, and we conducted a systematic analysis of course lecture notes. We cannot account for what students may have learned about the nonprofit sector since earning their bachelor's degree, although we feel that the undergraduate business degree lays the foundation for future learning, curiosity, and appreciation of the nonprofit sector.

We acknowledge that not all business people will be asked-or take the initiative- to be involved with NPOs, although given the growth of the sector and its needs for assistance, collaboration, volunteers, philanthropy, and so forth, it seems that few will avoid contact. Nor should they, in our view, given the size, scope, responsibilities, and importance of the nonprofit sector to civil society. Based on our study, we conclude that if a goal of schools of business administration is to prepare future business leaders, they should consider providing their undergraduate students with a stronger background to support interaction and involvement with the nonprofit sector.

\section{Notes}

1. The Financial Times European Business Schools 2005 Survey and the Elsevier Best Studies Research 2005 ranked the Erasmus University Business School as the number one business school in the Netherlands with the best Business Administration education (Financial Times, 2005; Rotterdam School of Management Erasmus University, 2006). RSM Erasmus University bachelor's education is ranked number one of all business faculties in the Netherlands by the Association for Quality Assurance of Netherlands Universities (RSM Erasmus University, n.d.). The RSM bachelor's degree excels in internationalization and scores highly on among other things: study breadth, level of education, graduates, mission and goals, external orientation, quality of staff, and quality of freshmen.

2. The stakeholder dialogue school prefers the term nongovernmental organization but the community involvement school prefers the term nonprofit organization.

3. The bachelor's degree program is offered to Dutch business students (business administration program) and to international business students (the international business administration program). Our research is limited to the regular Dutch business administration program.

4. In the RSM system, courses are taught by a lead faculty member, often supported by other faculty who give a few lectures in the course. A faculty member can be a lead teacher in more than one course. Four faculty members were not the lead teacher in the course; two faculty members were interviewed for the same course; and one faculty member was interviewed as the lead teacher for two courses. In all, 25 faculty members responded to our initial e-mail (4 responses) and our subsequent telephone calls (21 responses). Despite our repeated efforts, nonresponse amounted to $21.9 \%(n=7)$.

5. We could scan only 1 year of the Stichting Intermediair Rotterdam lecture notes (2004-2005), which poses a small concern because faculty members did not make their claims based on any specific year. It is possible that faculty members who claimed to mention nonprofit in their lectures have done so in other academic years. The lecture notes for 2005-2006 were not available. The three courses that could not be cross-checked in the Stichting Intermediair Rotterdam lecture notes are Business Skills, Statistics (Bachelor 1), and Mathematics.

6. We checked an additional 395 pages for five courses that were not included in our sample of 25 (due to nonresponse of faculty teachers): Macro-Economic and Institutional Context, 
Psychological and Social Processes, Organizational Behavior and Theory, Innovation Management, and Strategy Development and Implementation.

7. A detailed description of the coverage of the three nonprofit themes addressed in our survey and study in each course is available from the authors.

\section{References}

Austin, J. E. (2000). The collaboration challenge: How nonprofits and businesses succeed through strategic alliances. San Francisco: Jossey-Bass.

Baily, J. R. (Ed.). (2005). Service learning [Special issue]. Academy of Management Learning $\mathcal{E}$ Education, 4(3).

Drucker, P. E. (1989). What business can learn from nonprofits. Harvard Business Review, 67(4), 88-93.

Eliassen, K. A., \& Kooiman, J. (Eds.). (1993). Managing public organizations: Lessons from contemporary European experience. Thousands Oaks, CA: Sage.

Financial Times. (2005). Financial Times European business schools 2005-The top 50 business schools in Europe. Retrieved June 14, 2007, from http://media.ft.com/cms/34ddeae2-634511da-be11-0000779e2340.pdf

Fottler, M. D. (1981). Is management really generic? Academy of Management Review, 6, 1-12.

Herman, R. D. (2005). Board members of nonprofit organizations as volunteers. In J. L. Brudney (Ed.), Emerging areas of volunteering (ARNOVA Occasional Paper Series, vol. 1, no. 2., pp. 77-92). Indianapolis, IN: Association for Research on Nonprofit Organizations and Voluntary Action.

Hess, D. W. (n.d.). Integrating financial concepts of nonprofit organizations into the financial curriculum. Paper proposal, School of Business and Economics, Seattle Pacific University.

Mirabella, R. M., \& Renz, D. O. (2001). Nonprofit management outreach programs: An examination of institutional mission and setting. Public Performance and Management Review, 25, 14-29.

Mirabella, R. M. (n.d.). Nonprofit management education, current offerings in university-based programs. Retrieved June 13, 2007, from http://tltc.shu.edu/npo/

Mirabella, R. M, \& Wish, N. B. (1999). Perceived educational impact of graduate nonprofit degree programs: Perspectives of multiple stakeholders [Research Report]. Nonprofit Management and Leadership, 9, 329-341.

Mirabella, R. M., \& Wish, N. B. (2000). The "best place" debate: A comparison of graduate education programs for nonprofit managers. Public Administration Review, 60, 219-230.

Mirabella, R. M., \& Wish, N. B. (2001). University-based educational programs in the management of nonprofit organizations: An updated census of U.S. programs. Public Performance and Management Review, 25, 30-41.

Nonprofit management education: Selected bibliography. (n.d.). Retrieved April 28, 2006, from http://pirate.shu.edu/ mirabero/General\%20Bibliography.htm

O'Sullivan, E., Rassel, G. R., \& Berner, M. (2003). Research methods for public administrators. New York: Longman.

RSM Erasmus University. (2006). RSM Erasmus University, popular and the best in business administration/bedriffskunde. Retrieved June 14, 2007, from http://www.rsm.nl/portal/ page/portal/RSM2/Newsroom/ItemPortletPage?p_item_id=3976548\&p_pg_id=133\&p_ page_id=2610202

RSM Erasmus University. (n.d.). Samenvatting conclusies VSNU onderzoek [Summary conclusions VSNU research]. Retrieved June 14, 2007, from http://www.rsm.nl/portal/page/portal/ RSM2/Programmes/Bachelor\%20of\%20Science\%20in\%20Business\%20AdministrationBedrijfskunde/Programma/SUMMARY\%20VSNU

Salamon, L. M., Sokolowski, S. W., \& Associates (2004). Global civil society: An overview. New York: Nathan Cummings Foundation, Johns Hopkins Comparative Nonprofit Sector Project.

Sherman H. D., \& Coombs, G. (2006). Using a non-profit business partner to develop business management skills for MBA education. In C. Wankel, \& R. DeFillippi (Eds.), Research in 
management education and development, Vol. 5. New visions of graduate management education. Greenwich, CT: Information Age.

Smith, A. C., \& Green, F. B. (1993). Managing employees as if they were volunteers. S.A.M. Advanced Management Journal, 58, 42-46.

Social Science Research Network. (2006). International business schools rankings. Retrieved May 22, 2006, from http://hq.ssrn.com/Pub_Login.cfm?GoToUrl=/Rankings/Ranking_display .cfm?TRN_gID=12-.-TMY_gID=2

Stead, B. A., \& Miller, J. J. (1988). Can social awareness be increased through business school curricula? Journal of Business Ethics, 7, 553-560.

Taliento, L., \& Silverman, L. (2005). A corporate executive's short guide to leading nonprofits. Strategy \& Leadership, 33, 5-10.

Tulder, R. van (with Zwart, A. van der). (2006). International business-society management: Linking corporate responsibility and globalisation. New York: Routledge.

Ulrich, D. (1997). HR of the future: Conclusions and observations. Human Resource Management, $36,175-179$.

Voort, J. M. van der, Meijs, L. C. P. M., \& Whiteman, G. (2005). Creating actionable knowledge: Experimenting with service learning in a corporate regime. In C. Wankel \& R. DeFillippi (Eds.), Research in management education and development, Vol. 4. Educating managers through real world projects (pp. 149-180). Greenwich, CT: Information Age.

Wankel, C., \& DeFillippi, R. (Eds.). (2002-2006). Rethinking management education and development (Vols. 1-5). Greenwich, CT: Information Age.

Wartick, S., \& Wood, D. (1999). International business \& society. Oxford, UK: Blackwell.

Weitzman, M. S., Jalandoni, N. T., Lampkin, L. M., \& Pollak, T. H. (2002). The new nonprofit almanac and desk reference. New York: John Wiley \& Sons.

Lucas C. P. M. Meijs is professor of volunteering, civil society, and businesses at the RSM Erasmus University, Department of Business-Society Management. He initiated several experiments with service learning and teaches several courses on nonprofit management.

Esther M. Ten Hoorn, MScBA, is a research associate at RSM Erasmus University, Department of Business-Society Management. She is currently involved in a national study on the future of volunteering in the Netherlands.

Jeffrey L. Brudney, PhD, is the Albert A. Levin Chair of Urban Studies and Public Service at Cleveland State University's Maxine Goodman Levin College of Urban Affairs. Brudney has received national and international awards for his research and service and is a member of the editorial board of several journals. 